\title{
일본의 국제교육 및 개발교육 지원사업 현황과 시사점 \\ : 글로벌 인재 양성을 위해 무엇을 교육할 것인가
}

목 차

I. 서론

II. 개발교육 관련 용어 정의

1. 국제 동향

2. 일본의 개발교육 관련 용어

III. 일본의 국제교육 및 개발교육의 역사적 변천

1. 1970년대 : 개발교육 태동기

2. 1980년대 : 관심 고조기

3. 1990년대 : 전국 확산기

4. 2000년대 : 제도적 정착기

IV. 일본의 국제교육 및 개발교육 지원사업 추진 현황
1. 정부
2. 원조기관(JICA)
3. 시민사회
4. 학교교육

V. 결론 및 정책적 시사점

참고문헌 


\section{요 약}

한국국제협력단(Korea International Cooperation Agency, KOICA)는 2010년 ODA교육원을 설립한 이후 우리 국민의 공적개발원조(Official Development Assistance, $\mathrm{ODA}$ )에 대한 인식 제고 및 지지기반 확산과 국제개발협력 전문인력 양성에 기여하기 위해 다양한 교육과정을 운영하고 있다. 그러나 개발교육은 단순히 ODA에 대한 지지기 반 확산을 위해서 실시하는 것만은 아니다. 개발도상국의 빈곤문제나 인구, 질병, 환경 등 글로벌 이슈가 지구촌을 살아가는 우리 모두의 생존과 안녕에 큰 영향을 미친다는 점을 이해하고 우리 국민들이 글로벌 시민으로서 행동하고 실천할 수 있는 토대를 만들 며 나아가 개발협력에 국민참여를 촉진함으로써 효과적인 개발협력에 촉매역할을 한다 는데 더 큰 의미가 있다.

본 고에서는 개발교육에서 서구 선진공여국보다는 10 년 정도 늦게 시작했으나 정부 와 원조기관, 시민사회, 학교 등 여러 부문에서 활발하게 국제교육과 개발교육 지원사업 을 추진하고 있는 일본의 사례를 살펴봄으로써, 우리 정부와 $\mathrm{KOICA}$ 에 주는 정책 시사 점을 도출하고자 한다. 


\section{I. 서 론}

우리나라는 1991년 한국국제협력단(Korea International Cooperation Agency, 이하 $\mathrm{KOICA}$ ) 설립과 함께 본격적으로 개발협력을 추진 중인데 그동안 양적으로나 질적으로 많은 변화와 발전을 이루었다. 그러나 우리나라 ODA는 여전히 국제사회의 ODA/GNI 비율 권고 (0.7\%) 수준에 못 미치는 낮은 공적개발원조(Official Development Assitance, 이하 ODA) 규모(2016년 기준 $0.16 \%$ )를 보이고 있으며, 이 외에도, ODA에 관한 일반 국민의 인식 저조,1) 국내 관련기관간 정책일관성 부족, 원조분절화 등과 같은 거버넌스 문제 뿐만 아니라 ODA 추진을 위한 인적 인프라 및 성과관리 체계 미흡 등 여러 가지 과제를 안고 있다.

우리가 풀어나가야 할 $\mathrm{ODA}$ 정책 과제 중에서도 $\mathrm{ODA}$ 에 관한 국민 인지도를 개선하는 일은 $\mathrm{ODA}$ 규모를 확대하는 데 필요한 국민의 지지기반 측면에서 매우 중요하다. 그러나 개발 교육은 단순히 $\mathrm{ODA}$ 에 대한 지지기반 확산을 위해서만 중요한 것이 아니다. 개발도상국의 빈곤문제나 인구, 질병, 환경 등 글로벌 이슈가 지구촌을 살아가는 우리 모두의 생존과 안녕에 큰 영향을 미친다는 점을 이해하고 우리 국민들이 글로벌 시민으로서 행동하고 실천할 수 있는 토대를 만든다는 데 더 큰 의미가 있다. 오랜 개발원조 역사를 갖고 있는 '유럽의 선진원조공여 국에서는 개발교육을 단순한 국민의 인지제고 차원이 아닌 시민들이 당연히 누려야 하는 권리'로 인식하고 개발교육에 적극 대처하고 있다 (한국국제협력단, 2015). 2015년 수립된 '지속가능한 개발을 위한 2030 개발의제(Transforming our world: The 2030 Agenda for Sustainable Development)'에서도 개발교육에 대한 목표(SDG 4.7)를 별도로 설정하여 과거 새천년개발목표(Millennium Development Goals, MDGs)에서 보다 개발교육을 더욱 중요하게 다루고 있다.

(SDG4.7) 2030년까지 모든 학습자들이 지속가능개발 및 지속가능한 생활방식, 인권, 성평등, 평화와 비폭력 문화 증진, 글로벌시민의식, 문화적 다양성 및 지속가능개발에 대한 문화기여 인식을 위한 교육을 통해 지속가능개발을 증진하는 데 필요한 지식과 기술을 습득하도록 한다.

1) KOICA는 매년 ODA 및 KOICA 인지도 조사를 실시하고 있는데 2016년 조사에서는 ODA 제공을 알고 있다고 응답한 수는 $40.0 \%$ 이며 들어본 적 있는 응답수를 합치면 $73.5 \%$ 이다. 개발원조 제공에 찬성은 $60.4 \%$, 보통이 $33.8 \%$, 반대는 $5.8 \%$ 에 머물렀다. 원조제공 찬성 이유로는 우리나라가 과거 지원을 받았기 때문(39.6\%), 빈곤문제 해결에 도움(19.5\%), 국제사회안정과 평화공존(16.6\%), 국제적 이미지 외교에 도움(13.9\%) 순으로 조사되었다(KOICA 내부자료). 
By 2030, ensure that all learners acquire the knowledge and skills needed to promote sustainable development, including, among others, through education for sustainable development and sustainable lifestyles, human rights, gender equality, promotion of a culture of peace and non-violence, global citizenship and appreciation of cultural diversity and of culture's contribution to sustainable development.2)

우리나라가 2009년 경제협력개발기구 개발원조위원회(Organization for Economic Cooperation and Development Development Assistance Committee, 이하 OECD DAC)에 가입한 이후 처음으로 실시된 2012년 동료평가(peer review)에서도 대국민 이해증진을 위해 충분한 예산이 마련되어야 하며, 초·중·고교 대상 개발교육 시행과 같은 중요한 이해증진 영역에 더 많은 지원이 필요한 것으로 지적된 바 있다.3)

이 글은 우리나라 개발협력 분야에서도 개발교육이 보다 통합적 체계적으로 확대 추진되어야 한다는 문제의식에서 출발하였다. 일본은 개발교육에서 서구 선진공여국보다는 10 년 정도 늦게 시작했으나 정부와 원조기관, 시민사회, 학교 등 여러 부문에서 활발하게 국제교육과 개발교육 을 적극 추진하고 있다. 특히, 이러한 개발교육을 글로벌 인재양성 관점에서 중요하게 다루고 있다. 본 고에서는 일본의 사례를 살펴보고, 우리 정부와 $\mathrm{KOICA}$ 에 주는 정책 시사점을 도출하 고자 한다.

2) http://www.undp.org/content/undp/en/home/sustainable-development-goals/goal-4-qualityeducation/targets. (접속일: 2017.09.15.).

3) KOICA 내부자료 참조: OECD DAC, "Korea, Development Assistance Committee (DAC) Peer Review 2012”, 개발인식 증진의 중요성에 대해서는 DAC의 「Engaging with the Public - 12 Lessons from DAC Peer Reviews(2014)」, 「Good Practice in Development Communication(2014)」 등을 참조하기 바란다. 


\section{II. 개발교육 관련 용어 정의}

\section{1. 국제 동향}

제I장

\section{제II장}

개발교육의 기원을 거슬러 올라가 보면 초기 개발교육은 1960 년대 서구의 국제협력 NGO들 이 지원자들에게 제 3 세계의 현실을 알리고 모금을 위한 캠페인의 일환으로 시작되었다(田中治彦 외., 2016). 이후 개발전략을 토대로 시기별로 용어의 정의와 교육내용 및 방법 등이 변화를 겪어왔 는데, 모든 나라는 고유의 역사적, 사회문화적, 정치경제적 배경 하에서 개발교육을 실시하고 있으므로 다양한 용어가 사용되고 있다. 일본 국제협력기구(Japan International Cooperation Agency, 이하 JICA)와 국제개발센터(International Development Center of Japan, 이하 IDCJ)가 공동으로 실시한 국제교육에 관한 비교조사(2014b)에 따르면, 최근에는 개발 교육이란 용어는 영국이나 독일을 제외하고 거의 사용되고 있지 않으며 '글로벌 교육(global education)'이나 '글로벌 학습(global learning)'이라는 용어가 널리 사용되고 있다. 글로벌 교육이나 글로벌 학습은 과거 원조기관이나 $\mathrm{NGO}$ 들이 실시해 온 개발교육의 계보를 이은 것이다.4)

개발교육에서 선도적 역할을 하고 있는 '유럽 글로벌교육 네트워크(Global Education Network Europe, GENE)'는 2002년 네덜란드의 마스트리히트에서 열린 제1회 유럽 세계시 민교육 총회(European Global Education Congress, Maastricht)에서, 글로벌 교육 (global education)이란 “사람들이 세계의 현실에 눈과 마음을 열고, 모든 사람들을 위해 더 큰 정의와 평등, 인권을 실현하도록 일깨우는 교육”이라고 정의하였다. 여기에는 개발교육, 인권교육, 지속가능성을 위한 교육, 평화와 분쟁예방교육, 다문화 교육 등 세계시민으로서 갖춰야 할 다양한 글로벌 차원의 이슈를 포함한다(OECD DevCom, 2014a: 85). 대체로 개발협력에서 $\mathrm{DAC}$ 권고사항인 $\mathrm{ODA} / \mathrm{GNI}$ 대비 $0.7 \%$ 이상의 규모로 원조를 하고 있는 서유럽 국가들의 경우에는 개발교육도 매우 활발하며 국민, 정치인, 오피니언 리더 그리고 시민사회와 좋은 관계를 맺고 있다. 일반 대중에게 정보를 충분히 제공하지 않으면 개발 자금의 운영과 성과, 정부가 개발 협력을 수행하는 근거 등에 관해 오해가 빚어지기 쉽다

4) 우리나라의 경우에는 대학이나 기업에서는 '글로벌교육'이라는 용어를 주로 사용하고 있는 것으로 파악된다. 아울러 UNSECO 아시아태평양 국제이해교육원이나 일부 대학, 지자체, 시민단체 등에서는 '국제이해교육'이나 '세계시민교 육,'이라는 용어를 주로 사용하고 있다. 우리나라 교육부는 UNESCO '2015 세계교육포렴,' 2016년 '세계시민교육 (GCED) 국제회의' 개최 계기, '세계시민교육' 확산을 적극 추진중인 것으로 보인다. 'KOICA는 무상원조 전담기관으 로서 $\mathrm{ODA}$ 와 관련된 여러 글로벌 이슈에 초점을 맞추어 교육과정을 운영중으로 '글로벌시민교육,' '개발교육'이라는 용어를 주로 사용하고 있다. 
(OECD DevCom, 2014b: 15).5)

〈표 1〉 각국의 국제교육 관련용어 현황

\begin{tabular}{|c|c|c|c|c|c|}
\hline $\begin{array}{c}\text { United } \\
\text { Kingdom }\end{array}$ & Germany & Canada & United States & Australia & New Zealand \\
\hline $\begin{array}{l}\cdot \frac{\text { Global }}{\text { Education }} \\
\cdot \frac{\text { Global }}{\text { Learning }} \\
\cdot \frac{\text { Global }}{\text { Dimension }}\end{array}$ & $\begin{array}{l}\text { - Global } \\
\text { Education }\end{array}$ & $\begin{array}{l}\cdot \frac{\text { Global }}{\text { Education }} \\
\cdot \text { Global } \\
\text { Citizenship } \\
\cdot \text { Public } \\
\text { Engagement }\end{array}$ & $\begin{array}{l}\cdot \frac{\text { International }}{\text { Education }} \\
\cdot \frac{\text { Global }}{\text { Education }} \\
\cdot \frac{\text { Global }}{\text { Learning }}\end{array}$ & - $\frac{\text { Global }}{\text { Education }}$ & - $\frac{\text { Global }}{\text { Education }}$ \\
\hline 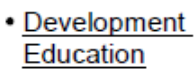 & - Development & & & & \\
\hline $\begin{array}{l}\text { - Global } \\
\text { Citizenship } \\
\text { - Citizenship } \\
\underline{\text { Education }}\end{array}$ & $\begin{array}{l}\text { - Intercultural } \\
\text { Education } \\
\text { - Citizenship } \\
\text { Education } \\
\text { - ESD }\end{array}$ & $\begin{array}{l}-\frac{\text { Multicultural }}{\text { Education }} \\
-\underline{\text { Citizenship }} \\
\text { Education }\end{array}$ & & - $\frac{\text { Citizenship }}{\text { Education }}$ & $\begin{array}{l}\cdot \frac{\text { Multicultural }}{\text { Education }} \\
\cdot \frac{\text { Citizenship }}{\text { Education }} \\
\cdot \text { Education For } \\
\text { Global } \\
\text { Citizenship }\end{array}$ \\
\hline
\end{tabular}

주: 밑줄이 그어진 용어는 현재 폭넓게 사용되고 있음을 의미

출처 : JICA and IDCJ (2014b)

\section{2. 일본의 개발교육 관련 용어}

일본에서도 개발교육과 관련하여 다양한 용어가 사용되고 있다. JICA와 IDCJ(2014a)는 각국의 개발교육에 관한 비교연구에서 관련 용어를 통칭하여 '국제교육'이라 칭하고, 각각의 문맥에 따라 사용되고 있는 '국제이해교육,' '개발교육,' ‘글로벌교육,' ‘시민교육, '지속가능한 개발교육(Education for Sustainable Development, 이하 ESD)' 등의 개념을 정리하였는데 그 내용은 아래와 같다.

〈표 2〉일본의 국제교육 용어 정의와 도입 배경

\begin{tabular}{c|c|l}
\hline 용어 & 정의 & \multicolumn{1}{|c}{ 배경 } \\
\hline & 문부과학성은 국제이해교육에 대해 특별한 정 & 제2차 세계대전의 반성으로부터 시작되어 \\
국제 & 의를 내리지는 않고 있으나 어린이들이 일본인 & 1947년부터 유엔교육과학문화기구(United \\
이해 & 으로서 자각을 갖고 주체적으로 살아가는 데 & Nations Educational, Scientific and Cultural \\
교육 & 필요한 자질이나 능력을 키우는 것이 중요함. & Organization, UNESCO)가 추진한 'Education for \\
& 국제이해교육센터(Nagoya Institute of & International Understaning'이 최초임. 일본은 \\
& Education for Development, NIED)는 자신과 & 1956년 UN 가입후 당시 사용 중이던 \\
\hline
\end{tabular}

5) OECD DAC Development Center 산하 개발 커뮤니케이션 네트워크 DevCom은 1988년 DAC 주요 공여국을 중심으로 설립되어, 현재 12 개국 1 개 다자기구가 정식 멤버로 활동 중이다. KOICA는 2015년부터 옵저버로 활동증이다. 


\begin{tabular}{|c|c|c|}
\hline 용어 & 정의 & 배경 \\
\hline & $\begin{array}{l}\text { 관련된 지구과제(인권, 환경, 개발, 타문화 이 } \\
\text { 해, 평화, 미래 등)를 포괄적으로 이해하고 지식 } \\
\text { 만이 아니라 공동의 미래와 공정한 지구사회를 } \\
\text { 만드는데 참여 기술, 참가태도를 키우는 종합 } \\
\text { 적인 교육활동으로 정의 }\end{array}$ & $\begin{array}{l}\text { 'Education for International Understanding } \\
\text { and Cooperation'을 '국제이해교육'으로 번역 } \\
\text { 하여 사용. } \\
\text { 당초 상호이해, 동서이해, UN이해가 중심을 이 } \\
\text { 룸. } 1974 \text { 년 UNESCO 의 교육권고에 따라 인권, } \\
\text { 환경, 개발 등이 국제이해교육에 포함됨. }\end{array}$ \\
\hline $\begin{array}{l}\text { 개발 } \\
\text { 교육 }\end{array}$ & $\begin{array}{l}\text { 개발교육협회(Development Education Association } \\
\text { and Resource Centre, DEAR)는 '우리들 모두 } \\
\text { 가 각자 개발을 둘러싼 여러 문제를 이해하고 } \\
\text { 바람직한 개발을 생각하고 함께 살아갈 수 있 } \\
\text { 는 공정한 지구사회 건설에 참여하는 것을 목 } \\
\text { 적으로 한 교육활동'이라 정의. } \\
\text { 외무성은 '개발교육이란 빈곤, 기아, 환경파괴 } \\
\text { 등 국제사회, 지구촌 현상을 파악하고 개발, 환 } \\
\text { 경, 인권, 평화를 비롯하여 다양한 문제에 관해 } \\
\text { 이해를 심화하고 국제협력, 개발협력의 중요성 } \\
\text { 에 대한 인식을 심화하기 위한 교육, 또한 개도 } \\
\text { 국과 선진국과의 관계를 포함하여 국제사회의 } \\
\text { 문제해결에 대해 어떤 형태로 참여하는 태도나 } \\
\text { 능력을 키우는 것을 목적으로 한 교육'이라고 } \\
\text { 정의. JICA도 이를 준용함. }\end{array}$ & $\begin{array}{l}\text { 개도국의 빈곤에 관한 관심으로부터 출발하여 } \\
\text { 초기에는 남북문제와 개발원조에 대한 이해가 } \\
\text { 중심. } \\
\text { 'Development Education(개발교유)'’이란 용어 } \\
\text { 가 공식적으로 사용된 것은 } 1970 \text { 년 } 10 \text { 월 스웨 } \\
\text { 덴에서 개최된 UNESCO와 식량농업기구(Food } \\
\text { and Agriculture Organization, FAO) 주최의 '학 } \\
\text { 교교육에서의 개발교육 워크샵.' } \\
\text { 일본어인 개발교육은 영문명을 직역한 것으로 } \\
\text { 일본에서는 1970년대 후반부터 사용 }\end{array}$ \\
\hline $\begin{array}{c}\text { 글로벌 } \\
\text { 교육 }\end{array}$ & $\begin{array}{l}\text { 일본 글로벌교육학회는 '이질적인 것과 공존하 } \\
\text { 고 인류역사를 함께 만들어가는 정신의 개발, } \\
\text { 자국·자민족 중심의 사고나 행동을 탈피하여 } \\
\text { 지구의 이익의 관점에서 자각하고 책임감을 갖 } \\
\text { 고 연대나 협력을 추구하며 문제해결에 참여하 } \\
\text { 는 글로벌시민을 육성하는 교육'으로 정의 }\end{array}$ & $\begin{array}{l}\text { 60년대말 미국에서 국가간 관계를 중심으로 한 } \\
\text { 'international education'을 대신하여 'global } \\
\text { education' 개념 등장. 일본에서는 80년대말부 } \\
\text { 터 국제이해교육을 보완하는 개념으로 사용중. } \\
\text { 해외에서 이 개념은 개발교육, 인권교육, 지속 } \\
\text { 가능성을 위한 교육, 평화와 분쟁예방교육, 이 } \\
\text { 문화교육을 포함하여 시민교육의 글로벌 측면 } \\
\text { 을 표현하는 것으로 사용되고 있음 }\end{array}$ \\
\hline $\begin{array}{l}\text { 국제 } \\
\text { 교육 }\end{array}$ & $\begin{array}{l}\text { 문부과학성은 '국제화된 사회에서 지구적 관점 } \\
\text { 을 수립하고 주체적으로 행동하기 위해 필요한 } \\
\text { 태도와 능력의 기초를 육성하기 위한 교육'으 } \\
\text { 로 정의 }\end{array}$ & $\begin{array}{l}\text { 2005년 문부과학성은 지금까지 국제이해교육 } \\
\text { 으로 추진되어 온 이문화이해 및 교류만이 아니 } \\
\text { 라 스스로가 국제사회 일원으로서 어떻게 살아 } \\
\text { 야 하는지 주체성을 한층 강화할 필요가 있다가 } \\
\text { 판단하고 해외자녀교유, 귀국아동학생교육, 외 } \\
\text { 국인아동학생교육, 국제이해교육 등을 포함한 } \\
\text { 개념으로 사용 }\end{array}$ \\
\hline $\begin{array}{l}\text { 지속가능한 } \\
\text { 개발을 위한 } \\
\quad \text { 교육 }\end{array}$ & $\begin{array}{l}\text { '지속가능한 개발(sustainable development)' } \\
\text { 란 '미래세대의 요구를 훼손하지 않으면서 현 } \\
\text { 세대의 요구를 충족시키는 개발'이나 '인간을 } \\
\text { 지탱하는 생태계가 갖는 능력의 범위 내에서 } \\
\text { 삶의 질을 향상시키는 것'이라고 정의하고 이 } \\
\text { 를 위한 교육을 ESD라고 정의 }\end{array}$ & $\begin{array}{l}\text { ‘Education for Sustainable Development } \\
\text { (ESD)'의 번역어로서, 문부과학성은 간략히 '지 } \\
\text { 속발전교육’이라고 칭하기도 했으나 최근에는 } \\
\text { '지속가능한 개발을 위한 교육'으로 통일 }\end{array}$ \\
\hline
\end{tabular}

출처: JICA and IDCJ (2014a), 제 9장 pp.1-2. 


\section{III. 일본 국제교육 및 개발교육의 역사적 변천}

일본의 개발교육도 상술한 개념 정의에서 볼 수 있듯이 국제사회의 개발전략 및 환경 변화를 토대로 역사적 변천을 겪어 왔다. 일본의 개발교육은 개발교육이 시작된 70 년대부터 2000년대 에 이르기까지 10년을 주기로 변화해 왔는데 간략히 살펴보면 아래와 같다.6)

\section{1970년대: 개발교육 태동기}

일본에서 개발교육은 서구 선진국보다 10년 늦은 1970년대말에 시작되었다. 1972년 '세계청년 회의(World Youth Forum)' 보고서에서 처음으로 '개발교육(development education)'이라는 용어가 사용되었다(JICA and IDCJ, 2014a:제 9장 p.3 재인용). 이 시기에는 서구 학계, 국제기구, $\mathrm{NGO}$ 등에서 추진되고 있는 여러 활동 소개가 주류를 이루었다. 동 시기에는 1965년 발족된 청년해외협력대(Japan Overseas Cooperation Volunteers, JOCV) 사업7)이 확대되었으며 Cross Road라는 기관 홍보지에서 '개발교육'이 특집으로 몇 차례 다루어졌다. 또한 1974년 유엔 교육과학문화기구(United Nations Educational, Scientific and Cultural Organization, 이하 $\mathrm{UNESCO}$ )이 제시한 ‘국제교육에 대한 권고사항’을 보면 과거 국제이해교육의 범위가 인권, 평화, 환경, 개발 등을 포함하는 개념으로 확대되는 등 UN에서의 개발교육에 대한 인식도 강화되었다. 1979년에는 일본 최초로 개발교육 심포지엄(The first symposium on Development Education in Japan)이 UN대학, 유엔아동기금(UN Childrens Fund, UNICEF)공동으로 개 최되었는데 동 심포지엄을 계기로 일본에 개발교육 개념이 본격적으로 소개되었다.

\section{1980년대: 관심 고조기}

1980년대 일본의 개발교육은 모색과 시행착오의 시대라고 불린다(湯本浩之, 2000 재인용).8) 1980년 심포지엄 참가자를 주축으로 '개발교육연구회'가 발족되었고, 일본 개발교육 보급을 위한 협의체로서 개발교육협의회(Development Education Council of Japan, DECJ)9)가

6) JICA and IDCJ (2014a) 제 9장 pp.3-6 참조

7) 우리나라 해외봉사단 파견사업에 해당.

8) 湯本浩之「日本における開發教育の歷史と現狀」財団法人國際開發センター『IDCJ FORUM 第2 号 特集/開發教 育』2000 年3 月。

9) 1982년에 개발교육협의회(Development Education Council of Japan, DECJ)가 설립되었으며, 2003년 비영리기구 (Non-Profit Organization, NPO)로서의 법적 지위를 얻고 개발교육협회(Development Education Association and Resource Centre, DEAR)로 기관명을 변경하였다. (출처: 개발교육협회(DEAR) 홈페이지, http://www. dear.or.jp/eng/eng01.html (접속일: 2017.09.14.)) 
설립되었다. 그러나 이 시기는 시행착오가 많았던 시기로 평가된다. 서구의 개발교육을 모델로 하여 개발NGO나 $\mathrm{YMCA}$ 가 모금 홍보활동의 일환으로 학습회나 강좌 등의 형태로 추진된 시기이다. 학교현장에서는 JOCV의 경험을 갖고 있는 일부 교사나 사회과 교원들을 대상으로 한 개발교육이 시도되었다. 개발교육 심포지엄은 1983년부터 매년 전국연구집회를 개최하여 개발교육 연구 실천 사례를 공유하였으며 1987년부터는 전국 개발교육추진연구회를 개최하여 관련단체의 경험 공유 및 인적 교류를 도모하였다.

한편 외무성에서도 1986년 개발교육에 관한 연구회를 설치하였으며, 문부성(우리나라 교육 부 해당)도 1989 년 학습지도요령 개정시 국제화 교육을 반영하는 등 개발교육에 관한 정부부처 차원에서의 관심이 높아진 시기이다.

제I장

제II장

포

\section{1990년대: 전국 확산기}

1990 년대는 1980년대 시행착오를 거쳐 개발교육이 비약적으로 발전하여 지역적으로 확대된 시기라고 말할 수 있다(湯本浩之, 2000 재인용). 여기에는 일본이 세계 제일 공여국으로 부상하 는 등 위상이 크게 높아지고 동시에 지속가능한 개발, 인간개발, 사회개발 등 새로운 개발전략이 수립된 시기이고, 외국인 노동자나 유학생 등의 증가와 함께 국제협력에 대한 사회적 관심이 높아진 점 등을 그 배경으로 들 수 있다.

특히, 1993 년부터 개발교육협의회는 외무성의 지원을 받아 지역세미나를 개최하기 시작하였 다. 전국을 6 개 그룹으로 나누어 각 그룹에서 실행위원회와 개발교육협의회 주최로 세미나를 지속적으로 실시하였는데 2003년까지 일본 전역에서 64회 개최되었다. 1995년은 지자체차원에 서의 국제협력 활동을 위한 원년으로서, 1970 1980년대에 설립된 각 시도군의 국제교류협회 에서 국제교류사업 이 외에도 국제이해추진사업이나 지역국제화사업, NGO지원연계사업 등으 로 사업을 확대하였다.

특히 이 시기에 일본에서는 개발교육이 저개발 문제에 대한 이해나 원조 참가 등과 같은 기존의 주제를 뛰어넘어 여러 글로벌 이슈를 포함한 개발 부문으로까지 확대되었으며, 1990년 대 중반부터는 참가형기법(participatory approaches) 등 개발교육 기법의 개발에도 많은 진전이 일어났다.

1993년에는 개발교육 시설로 '국제협력플라자(international cooperation plaza)'가 설치되 었고, 1998년에는 '21세기를 향한 ODA 개혁간담회’ 보고서에서 ODA에 대한 국민의 이해증진 
을 위한 개발교육의 중요성이 부각되었다(JICA and IDCJ, 2014a:제 9장 p.5 재인용). JICA에 서도 JICA 전신인 해외이주사업단(Overseas Technical Cooperation Agency, OTCA) 시절부터 실시해 온 고교교사 해외파견이나 에세이컨테스트 등의 활동을 통해 개발교육을 지원 하였다. 한편 문부성에서는 1996년 중앙교육심의회 보고서에서 '종합학습시간' 도입을 제안하 였는데, 그 예로서 국제이해교육을 언급하여 개발교육 발전에 중요한 계기가 되었다(JICA and IDCJ, 2014a:제 9장 p.5 재인용).

\section{2000년대: 제도적 정착기}

2000년대에는 일본의 개발교육이 학교교육으로 확대·보급된 시기이다. 상술한 '종합학습시 간을 활용하여 국제이해교육이 대폭 증가되었다. 특히 NGO나 각 지역의 국제교류협회와 교재 및 자료 입수, 강사파견 등을 통해 상호 교류가 늘어났다.(田中治彦, 2008 재인용)

2002년에 설립 20주년을 맞이한 개발교육협의회는 개발교육협회(Development Education Association and Resource Centre, DEAR)로 명칭을 변경하고 새로운 개발교육에 대한 목표를 바탕으로 개발교육의 개념을 재설정하는 등 개발교육 NGO로서 새로운 시대를 맞이하 였다. 2004년부터는 그간 외무성의 지원으로 개최해온 개발교육 세미나나 전국 개발교육담당자 회의를 대신하여, 각 지역별 실무자들이 참여한 가운데 정보교환이나 과제 공유를 할 수 있도록 실무자급 '개발교육전국네트워크 회의'가 매년 개최되고 있다.

한편, 2002년 요하네스버그에서 개최된 지속가능개발 세계정상회의(World Summit on Sustainable Development)에서 지속가능한 개발을 위한 교육(Education for Sustainable Development, 이하 $\mathrm{ESD}$ )의 중요성이 확인되어, 동년 12 월 $\mathrm{UN}$ 총회에서는 일본 정부의 제안 으로 2005년부터 '지속가능한 개발을 위한 10년(Decade of Education for Sustainable Development, DESD)'이 채택되었다. 이를 계기로 문부과학성10) 및 유네스코 일본위원회가 환경교육을 중심으로 $\mathrm{ESD}$ 를 실시하고 있다.

일본의 개발교육은 2003년 개정된 ODA 헌장(Japan's Official Development Assistance Charter)에서 개발교육의 중요성이 언급되면서 한층 강화되게 되었다. 특히 일본 외무성은 학교교육에서 종합학습시간 도입에 맞추어 '개발교육키트'를 제작 배포하고, 초·중등 학교 학생들의 글로벌 이슈에 대한 관심과 흥미를 유발할 수 있도록 '의무교육을 위한 개발교육

10) 일본 문부과학성은 우리나라 교육, 문화, 스포츠, 과학 담당부처에 해당한다. 
추진 홈페이지'11) 개설, 2003년부터 '개발교육 및 국제이해교육 콩쿨'을 개최해오고 있다. JICA 도 개발교육을 더욱 확대하여 다양한 이해관계자들에 대한 국제협력 출강 확대, 교재 및 자료 제공, 2001년부터 현직 교원 봉사단 참가제도 시작, 2006년부터 'JICA 글로벌 광장(Global Plaza)' 설치, NGO-JICA 협의회 내에 '개발교육소위원회'를 설치하는 등 다양한 개발교육과 정을 운영 및 지원하고 있다.

2011년, 2012년 개정 학습지도요령에는 $\mathrm{ESD}$ 관점이 포함되는 등 개발교육의 중요성이 보다 강조되었다. 그러나 교과학습시간 증가 정책에 따라 유연성 있게 추진되던 종합학습시간이 축소되어 국제교육 기회가 줄어든다는 우려도 제기되고 있다. 일본에서는 2000년대부터 ‘글로벌 인재육성'의 필요성이 각계에서 강조되면서 국제교육의 중요성 또한 점차 늘어나고 있다.

\section{제I 장}

\section{제II장}

포

11) 의무교육을 위한 개발교육추진 홈페이지: http://www.mofa.go.jp/mofaj/gaiko/oda/sanka/kyouiku/kaihatsu/ chikyu/index.html（접속일: 2017.09.11.). 


\section{IV. 일본의 국제교육 및 개발교육 지원사업 추진 현황12)}

\section{1. 정부}

일본 문부과학성은 1950 년대부터 국제이해교육을 추진해오고 있는데 앞서 제 ㅍ장에서 살펴 보았듯이 국제사회의 변화추세나 교육방침의 수정에 따라 동 국제이해교육도 변화해왔다. 문부 과학성은 2005년 ‘초·중등교육에서의 국제교육추진검토회’의 보고를 토대로 2006년부터 2009 년까지 ‘국제교육추진계획’을 실시하였다. 각 지역에 거점 학교를 설치하고 NPO 법인이나 대학 등과 연계하여 수업개발이나 워크샵, 모델 커리큘럼 개발 등을 연구하였다. 또한 연구 성과의 보급을 위해 ‘국제교육추진포럼'도 2007년부터 2009년까지 매년 개최하고 초. 중등 국제이해교 육실천 사례집, 실무자협의회, 국제기구 직원 출강 등을 추진하였다. 아울러, 2010년부터 문부과 학백서에서는 2010년부터 국제이해교육에 관한 독립된 장을 마련하여, '국제교육을 단순하게 추진하는 것만이 아니라 학교교육에서 주류화'하고 '글로벌 인재'육성의 관점에서 어학 능력 강화 등 국제교육을 강화해나가고 있다(JICA and IDCJ, 2014a: 제 9장 pp.6-8).

외무성은 전술한 바와 같이 ‘80년대말부터 개발교육에 관심을 갖고 개발교육 세미나 개최, 교재작 성 및 배포 등을 추진해왔다. 국제협력추진협회(Association for Promotion of International Cooperation, APIC)에 위탁 운영 형태로 1993년 '국제협력플라자(international cooperation plaza)'를 설치하였으며, 2001년에는 초중등교원 대상 「개발교육 및 국제이해교육 핸드북」을 발간하였다. 외무성의 국제협력플라자사업은 공개예산심의 과정에서 일부 업무를 JICA 글로벌플 라자(global plaza)로 이관하는 것으로 결정되어 2011년 폐지되었다. 외무성과 JICA는 국제협력 에 대한 일반 국민의 이해도를 높이기 위해 1990년부터 매년 '국제협력페스티벌(international cooperation festival)'을 개최하고 있다. 2005년부터는 ‘Global Festa JAPAN'으로 명칭이 바뀌었는데, 일본 최대의 국제협력 행사로 매년 10월 개최된다. 2016년에도 10.1 10.2 양일간 개최되어, 외무성, JICA, NGO, 국제기구, 각국 대사관, 기업 등 260여개 단체가 참여하였으며, 약 10 만 명이 다녀갔다.13)

2003년 일본의 ODA헌장 개정시에도 국민참여 확대의 일환으로 '개발교육은 ODA를 포함 한 국제협력 이해를 촉진함과 동시에 미래 국제협력 담당자를 확보하기 위해서도 중요하다. 이러한 관점에서 학교교육 등의 장을 통해 개도국이 안고 있는 문제, 개도국과 일본과의 관계,

12) JICA and IDCJ (2014a) 제 9장 pp.6 25 참조.

13) https://www.jica.go.jp/topics/2016/20161007_01.html (접속일: 2017.09.11.). 
개발원조가 수행해야 할 역할 등 개발문제에 관한 교육 보급을 도모하고 이에 필요한 교재 제공이나 지도자 육성 등을 수행한다’고 명기되었다(JICA and IDCJ 2014a).

\section{2. 원조기관(JICA)}

제I장

\section{제II장}

JICA는 1960년대 JICA 전신인 해외이주사업단(Overseas Technical Cooperation Agency, 이하 OTCA) 당시부터 학생을 대상으로 에세이 컨테스트나 교사해외연수 등을 실시 하였다. 1970년대에는 일본 정부에서 OTCA에 위탁하여 실시한 JOCV 귀국봉사단을 활용하 여 개발교육이 추진되었다. JICA는 본격적으로 1990 년대 후반부터 개발교육 지원사업을 실시 해오고 있다. JICA는 직접 개발교육을 추진하기 보다는 학교교육과 연계한 개발교육이나 시민 단체, 귀국봉사단을 활용하여 개발교육을 지원하는 역할에 무게를 두고 있다. 이러한 많은 사업 들은 JICA의 15 개 국내 사무소(거점 센터)를 통해 추진된다. KOICA도 지역 사무소로 승격한 부산센터와 2016년부터 6개 지역(강원, 대구, 전북, 인천, 경기, 제주)의 지자체 및 대학과의 파트너쉽을 통하여 국제개발협력센터(International Development Cooperation Center, $\mathrm{IDCC}$ )를 설치하고 개발교육, 조달설명회, 봉사단모집 설명회 등을 지원하고 있는데, 이는 $\mathrm{JICA}$ 의 경험을 벤치마킹한 것이다. JICA는 이밖에 각 지역의 국제교류협회 내에 국제협력추 진원을 배치하여 지역의 상담창구로서 개발교육 지원사업에 대응하고 있다. JICA는 1998년 '개발교육지원사업'조사를 통해 학교교육에서 개발교육 현황을 파악하고 향후 추진과제를 도출 하여 학교교육에서 필요한 개도국 정보, 실천사례, 교재, 인재육성 및 연수, 예산 등을 포함한 3 개년 액션플랜을 수립한 바 있다.

2003 년 독립행정 법인화 당시에는 독립행정법인국제협력기구법 제 13 조(업무의 범위) 제 4 호 에 '국민이 참여하는 국제협력을 촉진하기 위한 활동을 수행한다'고 정하고 기술협력, 유상자금 협력, 무상자금협력(제1 3호)과 나란히 JICA 업무로서 이러한 국제협력 촉진 활동을 명기하였 다. 같은 해 $\mathrm{ODA}$ 헌장 개정시에도 국민참여나 개발교육에 관한 내용이 추가되어 $\mathrm{JICA}$ 가 이러한 활동을 담당하는 역할을 수행하게 되었다. 2006년 시민참여 거점으로서 'JICA 글로벌플 라자'가 설치되었고, 2008년에는 시민참여에 관한 과제별 지침을 수립하였다. 동 지침에서 $\mathrm{JICA}$ 는 시민참여를'개도국과 일본을 연결하는 가교로서 일본 시민에 의한 국제협력 활동을 JICA가 촉진 및 지원하고 협력하여 사업을 수행하는 것'이라고 정의하였다(JICA, 2008). 대상 사업에는 개발교육지원사업, $\mathrm{NGO}$ 지원사업, 봉사단파견사업, 풀뿌리 기술협력사업, 기타 홍보 및 연수 사업 등이 포함되어 있다. 동 지침은 협력사업에 대한 시민참여의 의미에 대하여, $\triangle$ 개도국의 다양한 요구에 부응한 협력 추진, $\triangle$ 민간 섹터 등 다양한 일본의 개발경험 활용, 
$\triangle$ 국제협력 인재 육성, $\triangle$ 해외에서의 경험을 일본에 환원하는 것이라고 명기하고 있다.

$\mathrm{JICA}$ 는 글로벌인재양성 사업도 지원하고 있다. 2014년 문부과학성과 공동으로 실시한 국제 교육 비교조사시, 21 세기에 필요한 능력으로 기초능력, 사고력, 실천력 중 국제교육은 사고력과 실천력 습득에 효과적이라는 결론을 얻은 바 있다(JICA and IDCJ 2014b, 49-50). JICA는 문부과학성의 글로벌화에 대응한 교육내용 개정 검토에도 참여하였다. 또한 내각관방장관이 의장을 맡고 있는 글로벌인재육성추진회의 '글로벌인재육성전략(2012)'을 토대로 대학 학부생 의 글로벌 관점과 문제해결능력 습득을 지원하기 위해 '대학생 국제협력 현장답사 프로그램'14) 을 실시하고 있다. 2015년에는 40명을 대상으로 일본에서 사전 및 사후연수, 인도와 라오스 현장방문 조사를 지원하였다.

앞서 기술한 바와 같이, JICA나 일본 정부는 개발교육을 단순히 $\mathrm{ODA}$ 지지기반 확보차원으 로 바라보고 있지 않다. 일본 국민의 다양한 개발경험과 전문성을 활용하고, 글로벌 인재 양성을 도모하며 국제협력을 통해 얻은 다양한 글로벌 경험과 역량을 일본 사회에 환원시킨다는 측면에 서 정부, 원조기관이나 학교, 시민사회 등 다양한 부문에서 개발교육을 실시하고 있다. 다음 $<$ 표 $3>$ 은 JICA가 현재 수행하고 있는 개발교육지원 사업 현황이다.

\section{〈표 3〉 JICA의 개발교육지원 사업 현황}

\begin{tabular}{|c|c|c|c|}
\hline 사업 & 대상 & 사업개요 & 실적 \\
\hline $\begin{array}{l}\text { 글로벌 플라자 및 } \\
\text { 국내 사무소 } \\
\text { 방문 체험형 }\end{array}$ & $\begin{array}{c}\text { 초등학생 } \\
\text { 일반인 }\end{array}$ & $\begin{array}{l}\text { 체험형 프로그램으로, 개도국이나 지구촌의 다 } \\
\text { 양한 과제에 대한 이해를 제고하기 위하여 글 } \\
\text { 로벌플라자 및 전국 } 15 \text { 개 국내 사무소를 방문, } \\
\text { 개도국 생활상이나 지구촌의 여러 과제, 국제 } \\
\text { 협력 체험 전시, JICA 사업소개, 봉사단등 경험 } \\
\text { 경험담 소개, 참여형 학습, 직장 체험학습 등을 } \\
\text { 운영하고 있음. } \\
\text { 학교의 사회견학프로그램, 수학여행, 기타 학 } \\
\text { 습 프로그램 요청을 접수하여 무료 실시 }\end{array}$ & $\begin{array}{l}\text { 동경 글로벌 플라자 } \\
\text { 2015.9월까지 } 130 \\
\text { 만명 방문. } \\
\text { 나고야 글로벌플라 } \\
\text { 자는 2015.12월 } 50 \\
\text { 만명 돌파 }\end{array}$ \\
\hline 국제협력 출강 & $\begin{array}{l}\text { 초등학생 } \\
\text { 일반인 }\end{array}$ & $\begin{array}{l}\text { 개도국 현황을 파악하고 국제협력 필요성을 이 } \\
\text { 해하는 기회를 제공하기 위해, JICA 봉사단 경 } \\
\text { 험자 등을 학교에 강사로 파견하여 개도국 사 } \\
\text { 정이나 일본과의 관계, 국제협력에 관해 강의 }\end{array}$ & $\begin{array}{l}\text { 2003년 이후 전국에 } \\
\text { 서 연간 2000회 실 } \\
\text { 시 }\end{array}$ \\
\hline $\begin{array}{l}\text { 교사 } \\
\text { 해외연수 }\end{array}$ & $\begin{array}{l}\text { 초.중.고 } \\
\text { 교원대상 }\end{array}$ & $\begin{array}{l}\text { 실제 개도국에 방문하여 개도국이 처한 상황이 } \\
\text { 나 국제협력 현장, 개도국과 일본과의 관계에 }\end{array}$ & $\begin{array}{l}\text { 연간20개과정 } 160 \\
\text { 명에제공. }\end{array}$ \\
\hline
\end{tabular}

14) KOICA의 경우에는 매년 대학생 및 대학원생 대상 국제협력 논문공모전을 실시하고 수상자들에게는 개발협력 현장에 대한 이해증진을 위해 단기 현장방문 기회를 제공하고 있다. 


\begin{tabular}{|c|c|c|c|}
\hline 사업 & 대상 & 사업개요 & 실적 \\
\hline & & $\begin{array}{l}\text { 대한 이해 증진을 목적으로 그 성과를 미래세 } \\
\text { 대 교육에 도움이 되도록 국제이해교육, 개발 } \\
\text { 교육 관심 교원 대상으로 실시함. 연수참가후 } \\
\text { 에는 JICA와 협력하여 교육현장에서 국제이해 } \\
\text { 교육과 개발교육을 실시하고, 귀국보고서 작 } \\
\text { 성, 수업실시 결과보고 및 보고회 개최 등을 } \\
\text { 의무화 함 }\end{array}$ & $\begin{array}{l}\text { *행정담당관 대상 연 } \\
\text { 수실시(2015년 } 21 \\
\text { 명) }\end{array}$ \\
\hline $\begin{array}{c}\text { 개발교육지도자 } \\
\text { 연수 }\end{array}$ & $\begin{array}{l}\text { 교원학생 } \\
\text { 일반인 }\end{array}$ & $\begin{array}{l}\text { 개발교육, 국제이해교육담당자 육성을 목적으 } \\
\text { 로 함. JICA에서는 지금까지 축적해온 개도국 } \\
\text { 에 관한 자원을 활용하고 NGOLㅏ 교육위원회, } \\
\text { 국제교류협회 등 관계자간 연계를 통해 개발교 } \\
\text { 육을 효과적으로 수행하기 위한 연수기회 제공 }\end{array}$ & $\begin{array}{l}\text { 매년 } \\
9,000 \text { 명 }\end{array}$ \\
\hline $\begin{array}{r}\text { 에세이 } \\
\text { 컨테스트 }\end{array}$ & 중.고교생 & $\begin{array}{l}\text { 미래세대를 담당할 전국의 중. 고교생을 대상 } \\
\text { 으로 개도국의 현상이나 개도국과 일본과의 관 } \\
\text { 계에 대한 이해를 심화하고 국제사회에서 일본 } \\
\text { 과 각 개인이 어떻게 행동해야 하는가 등을 생 } \\
\text { 각하게 하는 것을 목적으로 실시함. } \\
\text { 여름방학 기간에 맞춰 국제협력이나 개발과제 } \\
\text { 를 주제로 한 에세이를 모집하고, JICA 내외 } \\
\text { 관계자의 심사를 거쳐 개인 및 학교 시상 }\end{array}$ & 연간 약 7만명 응모 \\
\hline $\begin{array}{c}\text { 글로벌교육 } \\
\text { 콩쿨 }\end{array}$ & $\begin{array}{l}\text { 초등학생 } \\
\text { 일반인 }\end{array}$ & $\begin{array}{l}\text { 글로벌교육을 실시할 때 활용할 수 있는 작품 } \\
\text { 을 발굴할 목적으로 실시 } \\
\text { 사진부분에서는 세계가 안고 있는 다양한 문제 } \\
\text { (교육, 보건의료, 환경, 수자원, 방재, 농촌개발, } \\
\text { 평화구축등)에 관해 배울 수 있는 사진, 일본의 } \\
\text { 국제협력 현장이나 개도국 현황을 알 수 있는 } \\
\text { 사진 공모. 글로벌교육부문에서는 글로벌 관점 } \\
\text { 을 갖은 교육실천 사례 등 모집 }\end{array}$ & $\begin{array}{l}\text { 2016년 } \\
\text { 사진 203작품, 글로 } \\
\text { 벌교육 부문 } 77 \text { 개 작 } \\
\text { 품 응모 }\end{array}$ \\
\hline $\begin{array}{l}\text { 국제협력 필드 } \\
\text { 스터디 }\end{array}$ & $\begin{array}{l}\text { 대학 } \\
\text { 학부생 }\end{array}$ & $\begin{array}{l}\text { 국제협력에 대한 이해 증진 및 글로벌인재 양 } \\
\text { 성 프로그램으로 일본에서 사전 및 사후 연수, } \\
\text { 개도국 현장 스터디 지원 }\end{array}$ & $\begin{array}{l}\text { 2015년 } \\
\text { 40명 }\end{array}$ \\
\hline 교재제공 및 대출 & $\begin{array}{l}\text { 초등학생 } \\
\text { 일반인 }\end{array}$ & $\begin{array}{l}\text { 국제이해교육/개발교육, 종합학습시간에 필요 } \\
\text { 한 교재(책, DVD, 웹 등)을 만들어 무료 배포. } \\
\text { 국내 거점 사무소에서 도서실을 운영, 자료 연 } \\
\text { 람, 교재 대출 등 추진 }\end{array}$ & \\
\hline $\begin{array}{l}\text { 국제협력체험 } \\
\text { 프로그램 }\end{array}$ & $\begin{array}{l}\text { 중학생 } \\
\text { 일반인 }\end{array}$ & $\begin{array}{l}\text { 개도국 가상체험, 개도국 연수생, 봉사단 경험 } \\
\text { 교류, 강의, 세미나 등 }\end{array}$ & \\
\hline
\end{tabular}

출처: JICA and IDCJ (2014a) p.64; IDCJ (2014) p.3-4; 2016 JICA연보, JICA웹사이트(https://www. jica.go.jp/) (접속일: 2017.09.11.) 등을 참조하여 저자 작성 


\section{3. 시민사회}

시민사회에서는 $\mathrm{DEAR}$ 를 중심으로 네트워크를 구축하여 각 지역에서 개발교육이 활발히 추진되고 있다. DEAR에 등록된 단체는 47 개 단체로 각 지역에 분포해 있다. 개도국을 대상으 로 하는 개발 $\mathrm{NGO}$ 는 일본 수도권에 집중되어 있으나, 개발교육을 담당하는 시민단체는 국내를 대상으로 하기 때문에 각지에 분포해있다(JICA and IDCJ, 2014a:제 9장 p9).

$\mathrm{NGO}$ 에 의한 개발교육은 $\triangle$ 교재 및 교보재 개발 및 보급, $\triangle$ 스터디투어, $\triangle$ 연구회, 강사파견, $\triangle$ 공정무역, $\triangle$ 캠페인, $\triangle$ 부수적 학습 등으로 분류되는데, 국제교육이나 개발교육을 전담하는 단체 외에도 개발 $\mathrm{NGO}$ 에서 단체 활동의 일부로서 국제교육 혹은 개발교육을 실시하기도 한다.

\section{〈표 4〉일본 NGO에 의한 국제교육 현황}

\begin{tabular}{|c|c|}
\hline \multicolumn{2}{|c|}{ 개발교육 및 국제교육을 중심으로 한 단체 } \\
\hline $\begin{array}{l}\text { 개발교육협회 } \\
\text { (DEAR) }\end{array}$ & $\begin{array}{l}\text { 1982년 설립. 일본 개발교육의 핵심 네트워크 조직으로 각종 회의개최, 정기 } \\
\text { 간행물 발간, 입문서 및 교재 발간, 강종 연수 및 강사파견, 정책제언, 해외 } \\
\text { NGO와의 네트워크 등 }\end{array}$ \\
\hline $\begin{array}{l}\text { 일본 크라스챤아카데미 } \\
\text { 관서세미나하우스활동 } \\
\text { 센터 }\end{array}$ & $\begin{array}{l}1967 \text { 년 개소. 개발교육연구회가 있으며 세미나, 스터디투어, 연구회 등 실시. } \\
\text { 개발교육 관련서적 출판 판매, 자료실 운영 등 }\end{array}$ \\
\hline $\begin{array}{l}\text { 가나가와 개발교육센터 } \\
\text { (K-DEC) }\end{array}$ & $\begin{array}{l}\text { 2005년 설립. 세미나 워크샵 기획 운영, 강사파견, 교재개발. JICA와도 협력 } \\
\text { (교사해외연수 등) }\end{array}$ \\
\hline $\begin{array}{l}\text { 개발교육을 생각하는 } \\
\text { 모임 }\end{array}$ & $\begin{array}{l}\text { 1984년 JOCV OB들에 의해 설립. 교재「지구의 동료들」 실천사례집 등 } \\
\text { 제작 }\end{array}$ \\
\hline $\begin{array}{l}\text { 사단법인 청년해외협력 } \\
\text { 대외(JOCA) }\end{array}$ & $\begin{array}{l}\mathrm{JOCV} \text { OB 모임으로 } 1983 \text { 년 설립. 각 지역에 모임이 있으며 지역사회에서 } \\
\text { 국제이해 및 협력증진을 위한 활동이나 JICA 봉사단사업 지원 활동 실시. } \\
\text { 교육현장을 위한 교재제작이나 판매, 강사파견, 교원 세미나 등. }\end{array}$ \\
\hline NIED 국제이해교육센터 & $\begin{array}{l}\text { 1997년 설립(전신 국제이해교육 아이치) 연수 세미나 개최, 조사연구, 상담, } \\
\text { JICA와도 협력 }\end{array}$ \\
\hline $\begin{array}{l}\text { 아시아태평양자료센터 } \\
\text { (PARC) }\end{array}$ & 1973년 설립. 세계 정보수집 및 배포, 연구, 시민학교 교육, 강연회 등 \\
\hline $\begin{array}{l}\text { 전국국제협력연구협의 } \\
\text { 회 및 전국국제교육협회 }\end{array}$ & $\begin{array}{l}\text { 전국 국제교육연구협의회는 JICA 사업과 연계를 통해 전국 } 2500 \text { 여개 등록 } \\
\text { 학교에서 개발교육 담당 교사 네트워크를 조직하는 연구회. 이를 모태로 } \\
\text { 현역 교원 제약 없이 활동을 수행하기 위해 전국국제교육협회를 2008년 } \\
\text { 설립. 교재제작, 웹사이트 운영, 국제교육 인터넷TV, 글로벌교육신문, 잡지 } \\
\text { 븡 발행. JICA와 연계하여 운영. }\end{array}$ \\
\hline \multicolumn{2}{|c|}{ 해외 국제교육 NGO 일본센터 } \\
\hline $\begin{array}{l}\text { 글로벌프로젝트 추진기 } \\
\text { 구(J-EARN) }\end{array}$ & $\begin{array}{l}\text { 세계 140개국이 참여하는 교육 네트워크로 ICT를 활용한 국제협동학습 } \\
\text { (International Interactive Collaborative Learning) 프로젝트를 실시하고 있는 } \\
\text { iEARN (International Education and Resource Network)의 일본센터 } \\
\text { (iEARN in Japan, J-EARN)임. ICT를 활용하여 세계의 어린이들과 상호 학습 }\end{array}$ \\
\hline
\end{tabular}




\begin{tabular}{l|l}
\hline & $\begin{array}{l}\text { 하는 글로벌 교육을 추진하며, 교류학교 알선 등 학습활동지원사업 및 교원 } \\
\text { 연수사업 등 추진 }\end{array}$ \\
\hline 일부 개발교육/국제이해교육 수행 개발 NGO \\
\hline 일본 유니세프 협회 & $\begin{array}{l}\text { '어린이와 교사의 광장'이라는 웹사이트 개설. 각종 자료, 학습교재, 실천사례 } \\
\text { Team Teaching, 유니세프 전시견학(12년 15,944명), 전국 유치원부터 대학 } \\
\text { 에 이르기까지 유니세프 학교모금으로 2억 12만엔 모금. }\end{array}$ \\
\hline 플랜 일본 & $\begin{array}{l}\text { 플랜 인터내셔널 일본 지부로 '83년 설립. 웹사이트를 통해 교사들에게 교재 } \\
\text { 제공, 강사파견, 이벤트 등 실시 }\end{array}$ \\
\hline
\end{tabular}

출처: JICA and IDCJ (2014a)

제 I 장

\section{제II 장}

포

제표장

\section{4. 학교교육}

일본 학교교육 현장에서는 주로 '국제이해교육'으로 추진되고 있다. 문부과학백서(2011)에 따르면, 국제이해교육은 사회과 교과, 도덕, 특별활동, 종합학습시간을 통해 실시되고 있다 (JICA and IDCJ, 2014a: 제9장 p.19).

종합학습시간을 활용한 국제이해교육에 대한 JICA의 한 조사(응답수 755건)에 따르면, 국제 교육의 학습내용중 이문화이해(69.6\%), 외국어 학습(67.9\%)이 주로 높고, 국제교류(45.5\%)나 일본전통과 문화(35.9\%)가 그 뒤를 이었다. 빈곤과 남북문제(6.3\%), 인권 환경 평화(20.2\%), 는 상대적으로 낮은 비중을 차지하였다(JICA and IDCJ, 2014a:제 9장 pp.21).

국제이해교육학회의 조사에서는 전체 응답자수 138 명 중에서 종합학습시간에 국제이해교육 을 실시한 경험을 갖고 있는 84명이었으며, 그 중, 학습내용 상위 5 개 항목은 세계(타국)의 생활과 문화(75\%), 타국(차지역) 이해(50\%), 세계와 일본의 관계(48.8\%), 영어학습과 케뮤니 케이션(48.8\%), 이문화이해(44\%) 순이었다. 이에 반해 평화문제(32.1\%), 인권존중(32.1\%) 등은 낮은 결과를 보였다. 학습방법에 대해서는 특정주제를 토대로 아동의 자주적 학습(60.1\%), 시청각교재 활용학습(52.2\%), 외국인 교류학습(49.3\%), 참가형 체험학습(48.6\%), 인터넷활 용학습(38.4\%), 현장연구 발표학습(38.4\%) 순으로 체험형 - 참여형 접근방식을 취하고 있다. 이는 일반적인 교과학습 방법과는 차이가 나는 것으로 국제이해교육은 '아동이 자주적 주체적 으로 참여할 수 있는 학습방법을 중시하고 있음을 알 수 있다(JICA and IDCJ, 2014a:제 9장 p.21). 


\section{V. 결론 및 정책적 시사점}

지금까지 살펴본 바와 같이, 일본의 국제교육 및 개발교육은 서구 선진공여국보다 10 여년 늦은 1970년대부터 시작되었으나, 외무성이나 문부과학성 등 관련부처와 원조기관(JICA), 시 민사회, 학교교육 등 다양한 부문에서 적극적으로 추진되어 왔다. 이러한 배경에는 각 개인이 살고 있는 지구환경이나 지구적 과제를 이해하고, 나아가 국제협력에 참여하여 문제해결을 도모하는 것이야말로 일본 국민을 글로벌 인재로 키우고, 나아가서는 일본의 글로벌 경쟁력을 제고하는 방법이라는 전략적 사고에 기반한 것으로 판단된다.

보다 포용적(inclusive)이고 지속가능한(sustainable) 개발을 위한 SDGs 시대에 글로벌 인재육성을 위해 우리는 무엇을 교육할 것인가? 지금까지 살펴본 일본의 국제교육과 개발교육 에서 얻을 수 있는 교훈과 정책적 시사점을 $\mathrm{ODA}$ 예산 측면, 정책체계 측면, 실시체계 측면 등으로 나누어 정리해보겠다.

첫째, $\mathrm{ODA}$ 예산 측면에서 보면, 우리나라도 $\mathrm{ODA}$ 자금을 활용한 개발교육 확대를 통해 글로벌 교육을 적극 추진할 필요가 있다. 2005년 발간된 네덜란드에 대한 '유럽 글로벌교육 동료심사(european global education peer review) 보고서'에 따르면, 유엔개발계획(UN Development Programme, UNDP)는 ODA 자금의 $3 \%$ 를 개발교육과 인식증진 활동에 사용 하도록 권고하고 있다(North-South Centre of the Council of Europe, 2005:10). KOICA의 개발교육 관련 예산은 ODA교육원, 지구촌체험관, 국제개발협력센터 등 개발교육 관련예산을 포함하여 $\mathrm{KOICA}$ 전체 예산의 $0.5 \%$ 에 불과하다. 일본 외무성이 제 3 자 평가로 실시한 「개발인 재육성 및 개발교육지원 평가」보고서(IDCJ 2014)는 정책제언을 통해'개발교육 지원사업은 현재 환경 하에서 교원이 국제이해교육이나 개발교육을 개시하거나 내용을 개선하고 싶을 때 중요한 지원이 되고 있으며, 향후에도 외무성 및 JICA는 현재 실시하고 있는 사업을 지속적으 로 실시하는 것이 바람직하다'고 강조하였다.

둘째, 정책 측면에서 보면, 우리나라도 지속가능한 개발을 위해 정부-원조기관-지자체 및 시민사회-학교교육이 연계하여 통합적이고 체계적인 전략 하에 글로벌교육 및 개발교육을 확 대 추진하고, 이를 위한 의견수렴 프로세스를 구축할 필요가 있다. '개발교육지원 전반에 관해 전문가나 관계자 의견교환을 정기적으로 실시하고 의견을 집약하여 반영하는 장을 설계할 필요 가 있다. 서로에 대한 이해를 서서히 심화함으로써 협동과 연계를 촉진할 수 있다'(IDCJ, 2014). 우리나라의 개발원조 실시체계상 분절화 이슈만큼이나 향후 개발교육에서도 KOICA를 포함한 원조기관, 지자체나 시민단체, 학교교육 등에서 교육내용의 질(quality), 기관간 중복이나 조정 
체계의 미흡 등 문제가 심화될 우려가 있는 바, 이에 대한 선제적인 정책적 검토와 조치가 필요한 때이다.

셋째, 실시체계 측면에서 보면, 개발교육의 지역간 격차 해소를 위해 현재 KOICA의 부산사 무소나 국제개발협력센터(현재 6개소 운영중)의 개발교육 과정을 확대하고, 다른 거점 지역에 도 이러한 개발교육 인프라를 구축할 필요가 있다. 일본은 JICA의 동경과 나고야 지역 글로벌 플라자 2 개소 및 15 개 국내 사무소가 운영하고 있는 개발교육 지원사업을 활용하여 각 지역에서 국제이해교육을 담당하고 있는 $\mathrm{NGO}$ 나 교원 등 핵심 구성원들 간의 네트워크 구축 및 지원을 통해 개발교육 활성화를 도모하고 있다. 이러한 핵심 네트워크 지원은 '개발교육 지원의 가장 큰 성과'로 평가되고 있다(IDCJ, 2014).

지금까지 일본의 개발교육 교훈을 통해 몇 가지 정책적 시사점을 살펴보았다. KOICA ODA 교육원은 앞으로 우리나라 개발협력의 양적 질적 성장 기반을 견고히 하는 개발교육 플랫폼으로 서의 역할을 수행하는 데 제한된 예산과 역량을 집중할 필요가 있다. 특히 글로벌 시민교육과 관련해서는 직접 교육과정을 운영하기 보다는 중장기 통합전략 수립을 위한 연구활동이나 관련 예산 확보, 교육과정 개발, 교사연수, 우수 강사양성 및 기관 육성 등 네트워크 기반 강화 등에 우선순위를 두는 것이 바람직하다고 생각한다. 국제개발 전문인력 양성 측면에서는 추후 기회가 되면 재차 논의하기로 하겠다.

$\mathrm{OECD}(2016)$ 는 '포용적인 세계를 위한 글로벌 역량'을 지식, 기술, 태도 3가지 차원에서 분석하며, ‘글로벌 역량이란 글로벌하고 이문화적인 이슈들을 다각적인 관점에서 비판적으로 분석할 수 있는 능력, 차이(differences)가 자신과 타인의 지각, 판단, 아이디어에 어떻게 영향 을 미치는지 이해하는 능력, 그리고 인간의 존엄성에 관한 공유 가치를 기반으로 다른 배경의 사람들과 개방적이고 적절하며 효과적으로 상호작용을 할 수 있는 능력'이라고 정의하였다. 따라서 KOICA ODA교육원이 추진하고 있는 다양한 글로벌시민교육과 개발교육의 의의는 비단 $\mathrm{KOICA}$ 가 ODA 지지기반 확산을 위해 추진하는 데 머물러 있지 않다. 이는 개발협력에 국민 참여를 촉진함으로써 효과적인 개발협력을 도모할 뿐만 아니라 우리나라의 글로벌 인재양 성과 국제경쟁력 강화에 촉매제 역할을 할 것이라는 점을 다시 한 번 강조한다. 


\section{〈참고문헌〉}

한국국제협력단. 2015.『개발교육이슈리포트』. 성남: 한국국제협력단.

2016.『개발원조(ODA) 및 $\mathrm{KOICA}$ 인지도 조사결과 보고서』. 성남:

한국국제협력단.

田中治彦(타나카). 2008. 國際協力と開發敎育:「援助」の近未來を探る. 東京: 明石書店.

田中治彦(타나카) 外. 2016. “SDGs と開㮁呚育：持續可能な開發目標のための學じ”東京：學文社.

IDCJ. 2014. “開發人材育成及び開發敎育支援の評価(第三者評価) 報告書.”東京: 株式會 社國際開發センタ(International Development Center of Japan, IDCJ)

JICA. 2008. 課題別指針「市民參加」JICA 내부자료 (https://www.jica.go.jp/) (접속일: 2017.09.08.).

. 2016. 2016 연보』. 東宗: 獨／行政法人或際妿)㙨娷 available at https://www.jica.go.jp/ english/publications/reports/annual/2016/c8h0vm0000aj21oz-att/2016_ all.pdf (접속일: 2017.09.11.).

JICA and IDCJ. 2014a. グローバル化時代の國際敎育のあり方國際比較調査 最終報告書 (第 1 分冊). 東京: 獨立行政法人國際協力機構.

.2014b.グローバル化時代の國際教育のあり方國際比較調査

最終報告書(第 2 分冊). 東京: 獨立行政法人國際協力機構.

North-South Centre of the Council of Europe. 2005. Global Education in The Netherlands. Lisbon: Council of Europe.

OECD DevCom. 2014a. Good Practice in Development Communication. Paris:

Organization for Economic Cooperation and Development.

2014b. Engaging with the Public. Paris: Organization for Economic Cooperation and Development.

OECD. 2016. Global competency for an inclusive world. Paris: Organization for Economic Cooperation and Development.

의무교육을 위한 개발교육추진 홈페이지: http://www.mofa.go.jp/mofaj/gaiko/oda/ sanka/kyouiku/kaihatsu/chikyu/index.html (접속일: 2017.09.11.).

개발교육협회(DEAR) 홈페이지, http://www.dear.or.jp/eng/eng01.html (접속일: 2017.09.14.).

JICA홈페이지: (https://www.jica.go.jp/) (접속일: 2017.09.11.).

UNDP 홈페이지: http://www.undp.org/content/undp/en/home/sustainabledevelopment-goals/goal-4-quality-education/targets/ (접속일: 2017.09.15.). 